\title{
REFLECTIONS ABOUT TEACHING NATURE OF SCIENCE MEDIATED BY IMAGES
}

\author{
Elaine A. Colagrande \\ University of São Paulo, São Paulo, Brazil
}

Simone A. de Assis Martorano

Federal University of São Paulo, Brazil

\author{
Agnaldo Arroio \\ University of São Paulo, São Paulo, Brazil
}

\begin{abstract}
In this paper a methodological experience is analyzed in exploratory nature, developed in short course promoted in Brazilian Chemistry Education Conference. The purpose of such activity was to rescue the views and beliefs that participants, pre-service and in service teachers, have about science and the scientific work and thus lead to reflection on the subject during the activity, by using previously selected images. The analysis of the accounts of the images evidenced that the common views already highlighted in research on the nature of science still occur with some frequency, conceptions that may limit the way of understanding of the teaching of science. The activity showed satisfactory the extent that provided moments of discussion and reflection on the subject, which may assist participants in their future educational activities.
\end{abstract}

Key words: nature of science, scientific knowledge, teacher training.

\section{Introduction}

The subject Nature of Science (NOS) and science teaching is not recent. For decades, the different academic research has been debating how views on science, conceptions and beliefs of both students and teachers are influencing the educational activities (Abd-El-Khalick and Lederman, 2000; Osborne, Collins, Ratcliffe, Millar, Duschl, 2003; Lederman, 1992; Lederman, 2006; Wellington and Lakin, 1994; Matthews, 1995; Acevedo, 2010, Harres, 1999; Almeida and Farias, 2011; Tobaldini, Castro, DellaJustina, Meglhioratti, 2011; Rubba and Harkness, 1993; Abd-El-Khalick and Akerson, 2004; Vazques Alonso, Manassero-Mas, Acevedo, Acevedo, 2008). According to Mc Comas, Clough e Almazroa (1998):

[...] The phrase "nature of science" is used to describe the intersection of issues addressed by the philosophy, history, sociology, and psychology of science as they apply to and potential impact science teaching and learning. As such, the nature of science is a fundamental domain for guiding science educators in accurately portraying science to students. (p.5)

In an investigation about the understanding of the NOS and classroom practice, Lederman (1998) focuses on the account, that teachers rarely plan their activities incorporating the knowledge about NOS in an intentional way. What are the reasons for which there is no such integration? Discussions and reflections on the nature of science, both with 
pre-service teachers and in service teachers promote an understanding of the construction of the most consistent science that somehow appears in their educational practices. Creating spaces and opportunities so that professionals in training or already working can discuss about the scientific work and the nature of this knowledge is essential to promote the identification of values and beliefs on the subject in an explicit way and share with their peers experiences in their teaching activities. In this context, the authors prepared a short course inserted in a national chemistry teaching event, with activities scheduled to discuss the ideas of NOS and provoke reflection on the subject and its reflection in teaching.

\section{A Few of the Main Philosophical Lines and Distorted Views about Science}

The nature of scientific knowledge is multifaceted. This perhaps justifies the reason for the existence of various forms of design knowledge and its construction. The human beings will elaborate their explanations of the facts observed, using different theories and often confronting them. The philosophy of science has long been concerned with this analysis, which is expressed in different philosophical lines of known science. In support of the work described here, table 1 was prepared, which contains the most emphasized ideas in each line of thought, which were analysed during the activity object of this report.

Table 1. Philosophical lines discussed in the event (Vasquez et al, 2001, p. 138-159).

\begin{tabular}{|c|l|}
\hline \multicolumn{1}{|c|}{$\begin{array}{c}\text { Philosophical } \\
\text { Lines }\end{array}$} & \multicolumn{1}{c|}{ Main Ideas } \\
\hline Logical Positivism & $\begin{array}{l}\text { Based on empirical facts and logical reasoning. Notice how } \\
\text { something saves and predates the theory. } \\
\text { The knowledge is accumulative. } \\
\text { Emphasis on verification: a theory is scientific when it is } \\
\text { empirically verifiable. } \\
\text { Scientific method as the only valid form of knowledge, based on } \\
\text { observational data and measurements }\end{array}$ \\
\hline Relativism & $\begin{array}{l}\text { Science is a social and human activity, considers personal } \\
\text { characteristics (interests, beliefs) and contextual (social, } \\
\text { economic, political). } \\
\text { The empirical evidence is not decisive for the construction of } \\
\text { scientific truths. Observation is preceded by a theory. } \\
\text { Scientific progress is not cumulative, there are always losses and } \\
\text { gains on changes of paradigms and theory rivals and scientific } \\
\text { development is not something clear and linear. }\end{array}$ \\
\hline Realism & $\begin{array}{l}\text { The position is based on the existence of a correspondence } \\
\text { between the beliefs about the world and the natural world } \\
\text { itself. } \\
\text { The aim of science is the search for true theories, according to } \\
\text { rational criteria, demonstrating that the theory may fail. } \\
\text { The science is the only valid way to knowledge. }\end{array}$ \\
\hline
\end{tabular}




\begin{tabular}{|l|l|}
\hline Pragmatism & $\begin{array}{l}\text { The pragmatism positions, also called instrumentalism, are } \\
\text { characterized by considering science an instrument whose } \\
\text { goal is to produce theories able to overcome most demanding } \\
\text { empirical contrasts. }\end{array}$ \\
Allows the progress in scientific theories. Scientific progress \\
is not a linear and cumulative concept, but a relative one and \\
which suffers losses and changes. \\
The theoretical constructions do not judge with truth or falsity of \\
criteria, but for their usefulness as tools, since they are intended \\
to give us a handle on the observable universe.
\end{tabular}

Besides discussing the philosophical lines chosen for the activity, the set of seven visions distorted about science were analyzed and scientific work presented in Gil-Pérez et al (2001,p.129-133): Empirical-inductive and theoretical view - a focus on "neutral" role of observation and experimentation, not considering the role of hypotheses and theories available in the guidance of a process; rigid view - The "scientific method" followed accurately; a problematic and a historical view - transmission of ready knowledge not discussing the difficulties and the steps of evolution that led to the scientific knowledge; cumulative view linear growth - scientific development is the result of linear growth, purely cumulative, ignores crises and deep refurbishments; individualistic and elitist view - Scientific knowledge produced by isolated geniuses, ignoring the role of collective and cooperative work and interactions between teams. Finally, socially neutral view - not consider the complex relationships between science, technology and society, scientists are beings "above good and evil", closed in their worlds and oblivious to the need to make choices. The theoretical basis, presented above contributed to the discussions held during the course and served as reference for the analysis of relations assigned by the participants in the activity, which will be detailed in the proposal results.

\section{Images Like Strategy of Activities}

The use of images is a practice that has been discussed and used in teaching different areas of knowledge. Especially in science teaching, there are reports that show the use of images to teach concepts (Gibin and Ferreira, 2013; Silva et al, 2006) and not to rescue conceptions about science, which confers to the activity proposed differentiated character. The answer to an image is linked to the perception that the person has on their environment or about a specific event. When observing an image, cognitive processes, beliefs and experiences of the observer will influence the way to interpret what is seen. The proposal for an activity with the use of images consisted of an alternative to evoke the participants to explain their way to understanding the nature of science and the construction of scientific knowledge and the relationships established for this construction, as, for example, the influence that society has on the scientific work.

\section{Development of the Activity}

The course was to elaborate apply in ENEQ XVII - Encontro Nacional de Ensino de Química (Brazilian Chemistry Education Conference), which occurred in August 2014 in the Ouro Preto city, state of Minas Gerais, Brazil. This event introduces great repercussion 
in an academic environment for being a space for discussion on various situations and issues involving the teaching of chemistry and has the participation of people from different regions of Brazil and other countries. The course was planned to occur in four hours, divided into two days of the event. As one of the activities proposed for that course was the use of images, which aimed to rescue beliefs and values that participants have about science and the scientific work. Would it be possible to make reflections on the nature of science mediated by images? The proposal was applied on the first day of the course, with the presence of forty-two participants. The activity with images was realized in three parts:

Part 1 - Six images were selected relate to any situation involving science or the observation of fact. The participants received the images and were encouraged to report in a descriptive way their perceptions and ideas about them. The images used are public domain.

Part 2 - At this stage there was a brief presentation of different philosophical perspectives and their lines of thinking described in Table 1 and there were also discussed distorted views about the development of science explored in the study by Gil-Perez et al (2001).

Part 3 - After the reflections made in stage 2, the participants again received the same images with the proposals that relate images, in a descriptive way, with the discussed philosophical lines. Table 2 shows the public domain images used and the planned objectives for each:

Table 2. Images used in the activity.

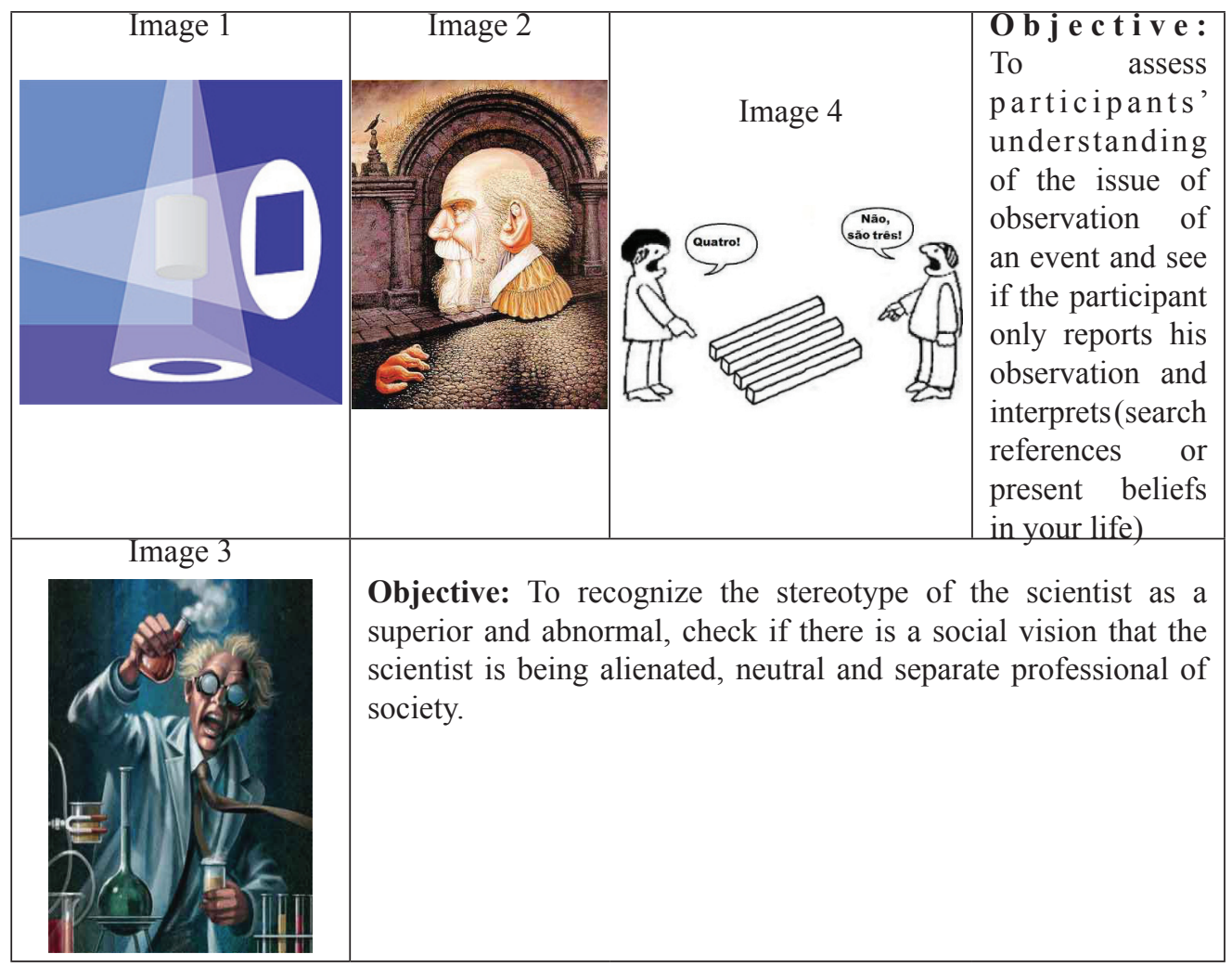




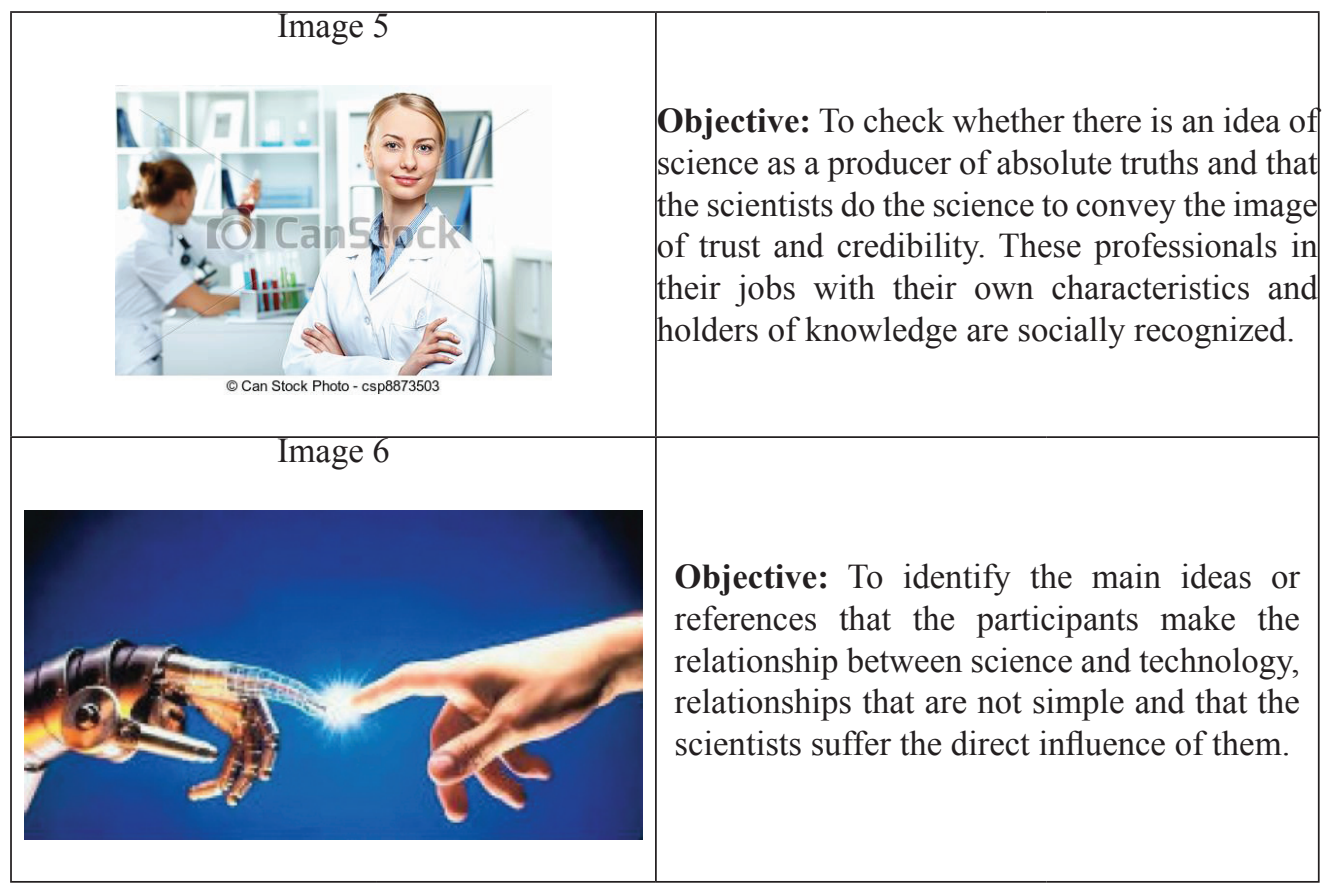

\section{Results}

According to the images and the objectives shown in Table 2, three categories were created to classify them:

- observer's perspective - images 1,2 and 4

- view of scientist's job - images 3 and 5

- relationship between science and technology - image 6

Based on the analysis of the activities delivered by the participants, the response categories were created for each group of images (Table 3).

Table 3. Categories created for responses - Part 1 of the activity.

\begin{tabular}{|c|l|}
\hline Image & \multicolumn{1}{c|}{ Category } \\
\hline 1,2 and 4 & $\begin{array}{l}\text { Observation "naive" of the image } \\
\text { Observer's theories about the image } \\
\text { Observer's beliefs about image }\end{array}$ \\
\hline 3 and 5 & $\begin{array}{l}\text { Observation "naive" of the image } \\
\text { Scientist as a being "crazy" } \\
\text { Social view of the scientist and doing science } \\
\text { Gender and the scientific work }\end{array}$ \\
\hline 6 & No category described \\
\hline
\end{tabular}


After the discussions with the group about different philosophical lines and distorted views about science and the scientific work, the participants were asked to relate to images. The results are highlighted in Table 4.

Table 4. Relationships with philosophical lines - Part 3 of activity.

\begin{tabular}{|c|c|}
\hline Image & Frequency of relationship \\
\hline 1 & $\begin{array}{l}\text { Relativism - } 18 \\
\text { Positivism - } 6 \\
\text { Pragmatism - } 7 \\
\text { Other answers - } 11\end{array}$ \\
\hline 2 & $\begin{array}{l}\text { Relativism - } 24 \\
\text { Positivism - } 2 \\
\text { Pragmatism - } 5 \\
\text { Other answers- } 11\end{array}$ \\
\hline 3 & $\begin{array}{l}\text { Positivism - } 12 \\
\text { Pragmatism - } 4 \\
\text { Individualistic and elitist view - } 8 \\
\text { Empiricist view - } 5 \\
\text { Other answers - } 13\end{array}$ \\
\hline 4 & $\begin{array}{l}\text { Relativism - } 27 \\
\text { Positivism - } 4 \\
\text { Pragmatism - } 3 \\
\text { Other answers- } 8\end{array}$ \\
\hline 5 & $\begin{array}{l}\text { Positivism - } 15 \\
\text { Pragmatism - } 7 \\
\text { Realism - } 6 \\
\text { Relativism - } 3 \\
\text { Other answers - } 11\end{array}$ \\
\hline 6 & $\begin{array}{l}\text { Realism - } 11 \\
\text { Pragmatism - } 8 \\
\text { Relativism - } 7 \\
\text { Positivism - } 3 \\
\text { Other answers - } 13\end{array}$ \\
\hline
\end{tabular}

\section{Discussion}

a) Part 1 - Images 1, 2 e 4

Observation "naive" of the image

On the three images the answers were found that just reported that the observer was seeing at the time, there was no inference or interpretation that could be related to their beliefs or values about the image analyzed. The amount of these kind responses was lower in image 4, relative to the images 2 and 1. Example of report: 
"I see an object of defined geometrical form and, depending on the angle it is viewed, it can have different geometric shapes. Vertically we see a circle and a rectangle horizontally." (Image 1)

\section{Observer's theories about the image}

In this category the highlight is that the observation and interpretation of the fact or situation depends largely on the perspective or the observer's point of view. The reports show that different looks can produce different conclusions, which may suggest that each individual sees the same issue differently. Chalmers (1993, p. 47) highlights that two normal observers see the same object from the same place under the same physical circumstances do not necessarily have identical visual experiences [...].Each observer carries itself values and beliefs about what is seen. The study of Nature of Science can help the observer to educate your look in the face to different facts. A selected report draws an analogy with the chemical exemplifying that each branch of this science has a different look to a specific event:

"Depending on the perspective that one looks or what point does" light is shed ", one sees a different projection. In chemistry one can make an analogy with its sub-areas: Analytical chemistry certainly "sees" a problem differently from physical-chemical (image 1)

"Those things are not exactly what we think at first impression. And if we look with greater attention and deepening we will notice other things and details" (Image 2)

\section{Observer's beliefs about image}

In this category the highlight is on the issue of observer's values or else the historical fact that the images remind. Indications of this classification do not appear in large numbers in the answers. For example:

"Rigidity; conservative; authoritarianism, the likeness of a slave and a woman with a child in her arms, a lying dog “(image 2)

\section{b) Part 1 - Images 3 e 5}

\section{Observation "naive" of the image}

As occurred, for the images 1, 2 and 4, there were responses that are meant as a description of what is observed, without any type of inference or interpretation. In this classification there are reports as:

"A scientist handling a chemical or a solution within a laboratory" (Image 3)

"A well-equipped laboratory and people satisfied with their workplace" (Image 5) 


\section{Scientist as a being “crazy”}

Scientist stereotype description as a being crazy or abnormal, there were no references to social issues. This category was evident only on image 3 , no citations for image 5 . The "creation" of a scientist with this profile has a historical context in which the recognized scientists were male, wearing their white lab coat and working on their own environment, isolated and unaware of the society. The English literature provides examples of this type of vision, like Frankenstein work, written in 1818 by writer Mary Shelley (1797-1851). In known history, Victor Frankenstein is a mix of scientist and doctor who decides to create a being from human remains. Another example is the story of Scottish Robert Louis Stevenson (1850-1894), entitled The Strange Case of Dr. Jekyll and Mr. Hyde, in which Dr. Jekyll creates a formula and the test itself, unleashing his perverse side, represented by Mr. Hyde. Some programs of TV and movies (including those based on both cited novels) also show the stereotype of the scientist as described above. Examples report:

"Shows the vision, a look that scientists in general are crazy and create surreal things and even worse for the world" (image 3)

"The idea that every scientist is mad" (image 3)

It was possible to observe that there was a rating that recognized a stereotype that, as already mentioned, has a historical context. However, there were no comments that showed how the influence of society affects the scientist's work.

\section{The social view of the scientist and doing science}

This category highlights the image that people or society in general has Scientist (for the image, 3); also appears the question of credibility that society assigns in the professionals who do science, that are successful professionals (image 5). Examples of this view appear in the citations:

"Common view between the people of the scientist is crazy who does a lot of smoke." (Image 3)

"An image of organization and security associated with research laboratories."(Image 5)

Important points appeared in the responses, illustrated in these two descriptions:

"The image can represent a major problem that is the appeal to scientific power, that is, seeking to explain facts or commercialize products using the appeal to authority, with the image of people who have credibility because they have scientific training" "A view of pure science, efficient and neutral"

Issues such as scientific power, science built by privileged, a science as true, neutral and that always brings the benefits that society expects. 


\section{Gender and the scientific work}

The responses in this category indicate the ascension of women in jobs that are usually held by men, in this case, scientists (image 5). In image 3, only one reference appeared in answers. This expression is also linked to the question of the historical context in which the scientist position would be primarily for people of the male sex. Trajectories as to the Polish chemist Marie Curie (1867 - 1934) show how the ascension of women in the scientific field was and still is full of obstacles, precisely due to the historic role that women play in the family and in society. The text of Maria Guimarães (2011) reports a meeting of scholars who discussed the role of women in the construction of science, showing a journey full of obstacles and prejudices. Examples reports:

"The woman occupying their space, which was fundamentally male long ago" (image 5)

"Science as a possible space for women, contrary to what was historically built, where science was predominantly male." (Image 5)

\section{c) Part 1 - image 6}

In the analysis of reports, the main ideas revolved around the link between man and technology. Some responses are characterized as a pure observation of the image, without any connection with the relations between science and technology and neither if society appears in these relations. Other responses made more detailed interpretations of the image:

"technoscience. It also shows the interaction of man with his own creations. In chemistry, we can say that the chemicals manipulate and study your own creations (chemical synthesis)"

"Association between science and technology: sometimes we think that technology is simply an application of scientific knowledge which is not always true"

An interesting point, which was not planned at the time of image choice, was the relationship that some participants have established between the figure and the famous Michelangelo painting exposed in the ceiling of the Sistine Chapel in Rome, known as the Creation of Adam.

"It refers to Michelangelo's Sistine Chapel painting which God and Adam nearly touched. Is a view of this painting by a technological look which shows the approach of the man with the machine / robotics and however we advance in technology will never reach the end and can never be the same. Anyway..."

"Futuristic representation of design made by Michelangelo in the Chapel ceiling in Rome"

Although there are references between man and technology, the quotes were somehow distant of the proposed purpose for the use of this image, that is, the relations established between science and technology and how society participates in these interactions. 


\section{d) Part 3 - Images 1, 2 and 4 (After the reflections made in part 2)}

On the three images it was possible to note that the most appropriate answers are those that relate the figure to a relativistic philosophical line. A large part of the information did not justify the choice of this line; those that presented justifications pointed to the fact that there are different views for the same event which can generate different interpretations. These interpretations depend on a referential or are the result of personal experiences. This expression is in agreement with that Vásquez et al (2001) indicate showing that relativism considers science as a social and human activity. Scientific knowledge can be produced in different ways and takes into account the personal aspects, such as beliefs and values, and also social aspects. These factors have a direct influence on the way of thinking of "doing science" and also on the production of scientific knowledge. Different knowledge will be produced and all have their space, being the result of different views, which in turn not only start the observation of a fact, but of values and theories that the observer has.

\section{e) Part 3 - Image 3 and 5}

For this analysis, the selected responses indicated what the activity requested: the participants relate the images to philosophical perspectives or distorted views about science. In general, the responses indicated only those prospects, without arguing the reason for your choice. Some participants indicated more than one line of thought, which in a sense shows that it is possible to do a mix of these ideas, not leaving the participant's choice so rigid to the point that makes an exact division. Others interpreted the answers, without making a direct relationship with the philosophical lines. The established relationships listed in Table 4, which considered the lines or more cited views in the activity. The answers indicated in the two images, one notices that logical positivism is the philosophical line that was more related to the images, than pragmatism. There were also indications referring to individualistic and elitist view. An inference that can be done about these responses is that positivism and the linear mode of construction of science are still present in chemistry courses, which may have influenced these relationships.

\section{f) Part 3 - image 6}

The most quoted philosophical line was realism, and no report sought to explain the reason for the choice. One possible inference would be that realism adopts a position that is based on the existence of a correspondence between the beliefs about the world and the natural world itself (Vásquez et al., 2001), but it was not clear in the responses.

\section{Considerations for the proposed activity and teaching}

After evaluation of the course, the authors considered that the strategy used was satisfactory as encouraged reflection and debate on the nature and construction of science. Interpretation of scientific facts involves more factors than simply observing an event, one must learn to see it and the study of Nature of Science can extend this look.

When the conceptions and beliefs about science are externalized, opportunities are opened for the teacher, in their future educational activities, to deepen and discuss with their 
students about the scientific knowledge construction process, showing that doing science is not something for the few and that society influences such construction. Important to highlight that the participants recognized common stereotypes in the scientific community, but there were a few quotes on the issue of the influence of society in building science. The participants were able to explain their views with the help of the images, but it was not possible to identify whether his dissertation about them was consistent with their mental representation of the theme.

The time available for the activity was a possible limitation in that identification. Another limiting factor is that people are not used to show explicitly their mental representations the way it was proposed in the activity, which signals the importance of strategies as reported be developed in teacher training courses, encouraging an expansion in the form of observing and interpret a scientific fact. A proposal to improve the activity would first require the representation of the themes explored in the images through drawings or diagrams, then work with the images and finally make this comparison.

Activities, as reported in this paper, can also be adapted for application in basic education. They will assist the explanation, in an explicit way, of ideas and images that students have about science, a fact that will bring important elements for teachers to plan strategies that facilitate the understanding and learning of their students.

\section{References}

Abd-El-Khalick, F., \& Akerson, V. L. (2004). Learning about the nature of science as conceptual change: Factors that mediate the development of pre-service elementary teachers' views of the nature of science. Science Education, 88, 785-810.

Abd-El-Khalick, F., \& Lederman, N. G. (2000). Improving science teachers' conceptions of the nature of science: A critical review of the literature. International Journal of Science Education, 22 (7), 665-701.

Acevedo Díaz, J. A. (2010). Formación del profesorado de ciencias Y enseñanza de la naturaleza de la ciencia [Science teachers training and nature of science teaching]. Revista Eureka sobre Enseñanza y Divulgación de las Ciencias, 7 (3), 653-660.

Almeida, A. V., \& Farias, C. R. O. (2011). A natureza da ciência na formação de professores: reflexões a partir de um curso de licenciatura em ciências biológicas [The nature of science in teacher education: reflections from a course of teacher preparation in Biological Sciences]. Investigações em ensino de ciências, 16 (3), 473-488.

Chalmers, A. F. (1993). O que é ciência afinal?[ What is this called Science?] (1 ${ }^{\mathrm{a} e d)}$. São Paulo: Brasiliense.

Gibin, G. B., \& Ferreira, L. H. (2013). Avaliação dos Estudantes sobre o Uso de Imagens como Recurso Auxiliar no Ensino de Conceitos Químicos [Students' evaluation about the use of images as auxiliary resource in teaching chemical concepts]. Química Nova na Escola, 35 (1), 19-26.

Gil-pérez, D., Montoro, I. F., Alís, J. C., Cachapuz, A., \& Praia, J. (2001). Para Uma Imagem Não Deformada do Trabalho Científico [For a non-distorted image of scientific work]. Revista Ciência \& Educação, 7 (2), 125-153.

Guimarães, M. (2011). Science, a (not very) feminine word. Revista Pesquisa Fapesp. Retrieved from http://revistapesquisa.fapesp.br/en/2011/12/01/science-a-not-very-feminine-word/? Accessed: 28/11/2014. 
Harres, J. B. S. (1999). Uma Revisão de Pesquisas nas Concepções de Professores Sobre a Natureza da Ciência e Suas Implicações para o Ensino [A review of research on teacher's conceptions about the nature of science and their implications for teaching]. Investigações em Ensino de Ciências, 4 (3), 197-211.

Lederman, N. G. (1992). Student's and teacher's conceptions of the nature of science: A review of the research. Journal of Research in Science Teaching, 29 (4), 331- 359.

Lederman, N. G. (1998). Teacher's understanding of the nature of science and classroom practice: Factors that facilitate or impede the relationship. Journal of Research in Science Teaching, 36 (8), 916-929.

Lederman, N. G. (2006). Research on nature of science: Reflections on the past, anticipations of the future. Asia-Pacific Forum on Science Learning and Teaching, 7 (1). Retrieved from http://www.ied.edu.hk/apfsit/ Accessed: 28.11.2014.

Martins, R. A. (1999). O que é ciência, do ponto de vista da epistemologia? [What is science, from the point of view of epistemology?] Caderno de Metodologia e Técnica de Pesquisa, 9, 5-20.

Matthews, M. R. (1995). História, filosofia e ensino de ciências: a atual tendência de reaproximação [History, philosophy, and science teaching: The present rapprochement]. Caderno Catarinense de Ensino de Física, 12 (3), 164-214.

Mc Comas, W., Clough, M., \& Almazroa, H. (1998). The role and character of the nature of science. In: W. F. Mc Comas (Ed.). The nature of science in science education (pp. 3-39), Netherlands: Kluwer Academic Publishers.

Osborne, J., Collins, S., Ratcliffe, M., Millar, R., Duschl, R. (2003). What "ideas-about-science" should be taught in school science? A Delphi study of the expert community. Journal of Research in Science Teaching, 40, 692-720.

Rubba, P. A., \& Harkness, W. L. (1993). Examination of pre-service and in-service secondary science teachers' beliefs about Science-Technology-Society interactions. Science Education, 77 (4), 407-431.

Silva, H. C., Zimmermann, E., Carneiro, M. H. S., Gastal, M. L., \& Cassiano, W. S. (2006). Cautela ao usar imagens em aulas de ciências [Caution when using images during science lessons]. Ciência \& Educação (Bauru) [online], 12 (2), 219-233. Retrieved from http://www.scielo.br/pdf/ciedu/v12n2/07.pdf. Accessed: 01/12/2014.

Tobaldini, B. G., Castro, L. P. V., Della Justina, A., \& Meglhioratti, F. A. (2011). Aspectos sobre a natureza da ciência apresentados por alunos e professores de licenciatura em ciências biológicas [Aspects over the nature of science presented by teaching graduation course of biological sciences]. Revista Electrónica de Enseñanza de las Ciencias, 10 (3), 457480.

Vázquez, A., Acevedo Díaz, J. A., Manassero Mas, M. A., \& Romero, P. A. (2001). Cuatro paradigmas básicos sobre la naturaleza de la ciencia [Four basic paradigms about the nature of science]. Argumentos de Razón Técnica, Sevilla, 4, 135-176. Retrieved from http://www.oei.es/salactsi/acevedo20.htm. Accessed: 04/08/2014.

Vazquez-Alonso, A., Manassero-Mas, M. A., Acevedo, J. A., \& Acevedo, P. (2008). Consensos sobre a natureza da ciência: a ciência e a tecnologia na sociedade [Consensuses about the nature of Science: Science and Technology in Society]. Química Nova na Escola, $27,34-49$

Wellington, J., \& Lakin, S. (1994). Who will teach the "nature of science"? Teacher's views of science and their implications for science education. International Journal of Science Education, 16 (2), 175-190. 
Received 17 December 2014; Accepted 18 March 2015

\section{\begin{tabular}{ll}
\hline & 0 \\
& Elaine A. Colagrande
\end{tabular}}

Chemistry Professor, Master in Science Education, Faculty of Education, University of São Paulo, São Paulo, Brazil.

E-mail: ecola@iq.usp.br

\section{$[\quad$ a}

\section{Simone A.A. Martorano}

PhD., Professor, Federal University of São Paulo, São Paulo, Brazil

E-mail: sialvesmartorano@gmail.com

\section{$\begin{array}{ll}\square & 0 \\ & \text { Agnaldo Arroio }\end{array}$}

PhD., Associate Professor, Faculty of Education, University of São Paulo, São Paulo, Brazil.

E-mail: agnaldoarroio@yahoo.com

Website: http://usp-br.academia.edu/AgnaldoArroio 